\title{
NATIONAL INSTITUTIONS, SPATIAL DIFFERENTIATION AND RACE: VARIATION IN CUBA'S POLITICAL REGIME
}

\author{
Jorge I. Domínguez
}

Jorge I. Domínguez was formerly a professor (1972-2018) at Harvard University. He has published numerous books and papers on Cuban politics and society. Website https:// jorgeidominguez.com

\section{Abstract}

Does territorial variation matter for institutional inclusion, how do officials discuss it and, given racial heterogeneity, how do interacting spatial and racial variations affect institutional design? This article examines the spatial anchoring of Cuba's Council of State members in 2003, 2008, 2013 and 2018. There has been little official public discussion regarding Council member territorial districts. Fidel Castro's presidency scored low on spatial inclusion, displaying marked territorial disparities in Council membership. Such disparities narrowed under Raúl Castro and Miguel Díaz-Canel, improving spatial inclusion. Selectors have also decoupled racial and territorial factors in choosing Council members. Relative to each province's Afrodescendant population share, there have been more Afrodescendant Council members than demographically to be expected in Afrodescendant-minority provinces. Through 2013 Council Afrodescendants were fewer than demographically to be expected in the three Afrodescendant-majority provinces. Only in 2018 did Afrodescendant population shares and Council membership shares match in Afrodescendant-majority provinces.

Keywords: Cuba, National Assembly, Council of State, spatial differentiation, race, elite selection, political regime

How do states take territorial variation into account in the design of institutions that purport to be broadly inclusive of its citizenry? How salient are spatial 
differences in official discourse regarding such institutional inclusion? In racially heterogeneous populations, how do interactions between spatial and racial variations affect institutional design choices?

Cuba's design of its constitutional institutions poses these questions well. Its elections to the National Assembly (parliament) are uncompetitive: the number of candidates for election equals the number of legislative posts to be filled. Therefore, Communist Party of Cuba leaders (Partido Comunista de Cuba, PCC) have emphasised dimensions of institutional inclusion other than accommodating political critics. The Assembly's design incorporates territoriality; its membership is proportionate to shares of the nation's population, organised in districts and provinces. The Council of State is the Assembly's executive committee; only Assembly Deputies may belong to the Council. In addition, Cuba displays racial heterogeneity across its provinces, but Afrodescendants are a majority of the population in the three easternmost provinces and almost half of the people in the City of Havana.

This article examines the spatial anchoring of members of Cuba's Council of State in 2003 (Fidel Castro's, henceforth F. Castro, last Council), 2008 and 2013 (Raúl Castro’s, henceforth R. Castro, Councils), and 2018 (Miguel Díaz-Canel's first Council). A new Council membership was selected on each of those years following a noncompetitive National Assembly election. There was a lack of official public discussion regarding the territorial origins of Council members and their marked territorial disparities. Spatial inclusion was especially problematic during Fidel Castro's last Council presidency. Such territorial disparities narrowed under the Raúl Castro and Miguel Díaz-Canel Council presidencies, thereby improving spatial inclusion, notwithstanding a persistent lack of public discussion regarding this criterion for inclusion. Selectors of Council members have also decoupled racial and territorial factors in the configuration of Council membership across the three presidencies. Relative to each province's Afrodescendant population share, there have been more Afrodescendant Council members than demographically to be expected in Afrodescendant-minority provinces. Through 2013, Council Afrodescendants were fewer than demographically to be expected in the three Afrodescendant-majority provinces. Only in 2018 did Afrodescendant population shares and Council membership shares match in Afrodescendant-majority provinces.

\section{Comparative Context}

How do other states accommodate territorial and ethnic heterogeneity? In the rationalist tradition, Riker (1964) argued that federalism is one solution to the organisation of territorial politics, especially in large countries with democratic 
regimes, which grant substantial autonomy to subnational territorial units. Such has been the trajectory in Australia, Brazil, Canada, the German Federal Republic, India, Mexico, the United States and South Africa. In some of these cases, federalism is a means to accommodate the interaction between territorial and ethnic variation. India's States Reorganisation Act of 1956 carved the boundaries of States in the Union to approximate major linguistic boundaries. Canada's federalism anchors Francophone autonomy in Quebec.

Federalism has also helped some authoritarian states to manage multilinguistic territoriality and elite conflicts. In the former Soviet Union, Soviet Republic boundaries were drawn to approximate the location of Soviet "nationalities". The former Yugoslavia also sought to match federal state boundaries with ethnolinguistic demographic distribution. Federalism helped to manage elite politics in Mexico under its long authoritarian regime (1917-2000). In practice, however, centralised power has predominated in formally federal authoritarian states.

A second approach to managing ethnic variation reserves seats in the national legislature for ethnic, religious, communal or national minorities (Reynolds 2005). These may have territorial bases, but they need not. In some form, these practices are common in European and South Asian democracies, with more modest examples in Latin America (Colombia, Venezuela) where the legitimating myths of single-peoplehood, blind to differences in race, ethnicity or language, have long been the dominant trope, notwithstanding efforts by Afro-Latin or indigenous social movements to raise concerns about their exclusion (Rice 2020, headlining special issue).

Revolutionary parties embed a third approach regarding ethnic variation, possibly interacting with territory. They seek to integrate radically and expect loyalty to the goal of the revolution, evident in diverse examples such as the rebellious 13 British colonies in North America, France, Mexico, the Russian empire, China, Vietnam and Iran. Yet even some revolutionary parties reserve national parliamentary seats to accommodate ethnic variation. China, Laos and Vietnam, whose regimes are heirs to revolutions, ensure a fixed share of their respective parliaments for ethno-linguistic minorities, matching their national demography to parliamentary seat shares. However, such inclusion occurs in centralised unitary states and it pertains to ethnic minorities, some of which are territorially based while others are not. In China, ethnic minorities (about 9\% of the population) are allocated approximately $12 \%$ of its parliamentary seats and $16 \%$ of its National Standing Committee seats (Inter-Parliamentary Union 2018). Laos' government estimates that nearly 34\% of its people belong to minority ethno-linguistic groups (Government of Lao People's Democratic Republic 2006: 4); 38\% of Laotian National Assembly members originated from these groups (Inter-Parliamentary Union 2011). Vietnam's non-Kinh (Viet) 
population is approximately $14 \%$; ethnic minorities account for $17.5 \%$ of Vietnam's National Assembly (Palmieri 2010: 4). In all three countries, however, adherence to the revolutionary legacy and party is paramount; there is no lawful inter-party or inter-ethnic competition.

One additional frequent outcome from revolutions is that its top national leaders remain in power for many years after the successful revolution. In communist revolutions, the mechanism for leadership persistence is the communist party. Heirs to the Bolshevik and the Chinese revolutions retained significant national leadership roles for many years. In non-communist revolutions, this foundational propulsion of the elite is also evident. For 32 of the first 36 years following the adoption of its Constitution, the president of the United States hailed from the State of Virginia. Following the Mexican revolution and the adoption of the Constitution in 1917, six of the seven presidents were from the country's northernmost tier of states, and four of those six came from the State of Sonora.

Cuba features a centralised communist authoritarian regime, in a unitary state, heir to a revolution that won power in 1959. Its top leaders retained power into the 21st century. Cuba is also racially heterogeneous; a large fraction of its Afrodescendant population is territorially anchored. How have rebellion veterans been included in top leadership posts and how have territorial variation and territorially anchored Afrodescendant citizens been accommodated on its key constitutional institution, the Council of State?

\section{The Cuban Context}

Cuba's constitutions (1902, 1940, 1976, 2019) consistently established a unitary state. Since 1976, the national constitutional institutions feature a National Assembly and a Council of State. The Assembly has ordinarily met twice per year. Its plenary sessions typically last a couple of days; its commissions meet for the three or four days before each plenary session. Between Assembly sessions, the Constitution authorises the Council of State to enact decree-laws, which are perfunctorily ratified at the Assembly's next session. The Council may also approve treaties, revoke all decisions of provincial and municipal governments, appoint or remove ambassadors and provincial governors, suspend all Supreme Court justices, create new state administrative entities and regulate foreign investment, among other powers (Constitución 2019: Article 122). The Council of State issues decree-laws even on non-urgent topics that could have waited for debate at an ordinary Assembly session (Consejo de Estado 2020). Thus, the Council, not the Assembly, is the key constitutional institution.

Constitutional amendments approved in 1992 mandated that citizens directly vote for National Assembly Deputies (hitherto Deputies had been selected 
indirectly) provided the number of candidates for election equals the number of parliamentary seats to be filled. The 2019 Constitution's Article 5 establishes a single-party system. By design, therefore, the Assembly does not include the nation's diverse political opinions. Official leaders stake their claims to institutional inclusion on other grounds.

In April 2018, the presidency of Cuba's Council of State and Council of Ministers passed from R. Castro to Miguel Díaz-Canel. At his inaugural address, Díaz-Canel celebrated that the 2018 election shaped the membership of the new Assembly and Council to approximate Cuba's gender and racial demographics, "almost in the same proportion as the statistics define the nation" (Díaz-Canel 2018). In his valedictory speech, outgoing President R. Castro also cheered the inclusion of women and Afrodescendants in these two institutions (Castro 2018). Commissions staffed by official organisation members vet candidates to ensure such inclusion; thus, the Assembly's and the Council's members look like the nation's people. Neither Díaz-Canel nor R. Castro made any reference to the inclusion of Council members from across the provinces, however, nor, in his time, did F. Castro.

Notwithstanding the lack of discourse regarding territorial inclusion, over the years national leaders have taken geographic differences into account in their design of institutions. At the end of the Ten Years War in 1878, the Spanish colonial government split Cuba's three provinces into six, an enduring design following the end of Spanish and direct US rule (although the names of some provinces changed). In 1976, those six provinces were redrawn into 14, plus one small special municipality. In 2011, a new reorganisation brought the number to 15 (see list, Table 1). The Assembly's membership must be proportional to population by districts, thereby guaranteeing each province's inclusion in the Assembly according to its population. In short, Cuba's national leaders regard geographic space as a salient issue for parliamentary design, but has it been a salient criterion for membership on the more powerful Council of State?

Territoriality also interacts with the racial distribution of Cuba's population. In the early 1930s, the disproportionate concentration of Afrodescendants in the easternmost region caught the attention of the pre-revolutionary Communist Party of Cuba. The Sixth World Congress of the Communist International (the "Comintern") programme celebrated the Soviet Union's grant of "full rights of national self-determination" to ensure "to the various nationalities of the Union not merely formal but real equality". It pledged that communist parties in "colonial countries" would struggle for "complete equality for all nationalities and races” (Degras 1959: 511, 524). The Cuban communist party had paid little attention to race issues but accepted the Comintern's new commitment. The Cuban party launched a campaign for racial equality, while also characterising 
blacks as a "national minority" with a common territory, economy, language and culture. At its first national conference in 1934, the communists declared that the black question in Cuba was a national question. The Party would support the creation of a black independent state in Cuba, located at the so-called faja negra ("black belt") in Oriente province, then Cuba's easternmost, where it estimated that Afrodescendants accounted for more than half of the population (de la Fuente 2001: 192). In 1935, the communists abandoned the plank of racially based territorial autonomy as a mistake, but that idea had spatial and demographic credence, then and now.

In the 2012 Census, eleven of Cuba's 15 provinces reported a non-white population between $16 \%$ and $26 \%$. On the other hand, the non-white population was recorded as $46 \%$ for the City of Havana, $58 \%$ for Granma, $74 \%$ for Santiago de Cuba and $76 \%$ for Guantánamo (author's calculations, from ONEI 2016: table 1). Granma, Santiago and Guantánamo, home to large majorities of Afrodescendants, were the three easternmost provinces, successors of Oriente province and its faja negra. However, before as well as since the 1959 revolution, Cuba's laws have prohibited race-based political parties and movements. Since 1959, official leaders claim to have solved racial problems (de la Fuente 2001). Yet racial concentration according to territory has persisted.

Cuba was home to slavery longer than other Spanish American countries; racial differences still affect its Afrodescendant population adversely. Sawyer (2006: chs. 5-6) demonstrated that the limited market openings during the 1990s facilitated the reappearance of some structural racial inequalities while reinforcing others that had endured. Moreover, given the professed allegedly colour-blind "gains of the revolution", Sawyer's in-depth interviews and surveys showed that many whites believed and reported that black disadvantage in the new economy could only be explained because blacks were inherently inferior. Sawyer's work showed such expressed racism to be more severe in Cuba than in the Dominican Republic, Puerto Rico or the United States. Espina and Togores (2012: 276), working from the 2002 Census, showed that non-whites were overrepresented among those living in housing units classified as barely acceptable or bad and under-represented among leaders, managers, professionals, scientists and the self-employed whose income was typically higher. Working from an original survey conducted in 2017-18, Hansing and Hoffmann (2020) showed that the racialised emigration patterns of the past made for highly unequal access to family remittances; whites had been disproportionately present in that emigration. Because remittances had become the key for startup capital in the new private economy, Afrodescendants were at a disadvantage in launching businesses. Racial bias, they noted, is a grave issue. How may race and territory be accommodated in choices for Council of State membership? 


\section{Data, Sources and Methods}

The Cuban government's statistical agency publishes annual population statistics. From the start of the 21st century, the population stabilised at somewhat over 11.2 million people (ONEI 2019a, 2019b). The same agency published the country's racial distribution by provinces from the 2012 general population census (ONEI 2016).

Cuba has published the list of members of the Council of State, with brief biographies ("Integrantes" 2018; "Miembros" 2014, 2008, 2003). The size of the Council of State remained 31 members for all years under study, which are those of each Council membership's original selection. The 2012 Census is the basis for calculating the non-white share of the population for each of those four years. Table 1 presents the percentage of the population and the percentage of the Council of State per province, while Table 3 does so for the percentage of the non-white population.

A slight provincial reorganisation occurred between the 2008 and 2013 Council selections. In 2003 and 2008, the province with the name of La Habana included approximately what by 2013 would become the provinces of Artemisa and Mayabeque. Starting in 2013, the province formerly called Ciudad de La Habana was renamed La Habana. (Some additional small geographic and population differences do not affect the present analysis.) For Tables 3 and 4, the calculation of $\mathrm{E}^{*}$ Council (see below) for 2003 and 2008 combines the non-white population in the 2012 Census for Artemisa and Mayabeque to approximate the non-white population of La Habana province for those years. The Isle of Pines special municipality has a small population and never produced a Council member; it is excluded here.

Tables 2 and 4 present three well-known indexes of concentration, inequality and dispersion. The Herfindahl-Hirschman concentration index is widely used in studies of market concentration and anti-trust actions. The Gini index of inequality is a long-standing measure that informs the World Bank and social movement activists, among others. The standard deviation (how spread out the numbers are) informs financial analysis regarding historical price volatility. All three are applicable here. They are calculated for the population and the Council of State membership per province (Table 2) and for the non-white population, the actual non-white membership of the Council and the "expected" (E"Council) non-white membership of the Council per province (Table 4). E*Council multiplies each province's non-white population percentage by the province's assigned number of Council members per year. E* Council would be the outcome if the number of non-white members of the Council from each province were to match the non-white share of each province's population. 
Herfindabl-Hirschman Index (HHI). Where $n$ is the number of observations and $S_{n}$ is the share of the $n$th observation in the set of observations, then HHI expresses the degree of concentration of the set of observations:

$$
H H I=S_{1}^{2}+S_{2}^{2}+\ldots+S_{n}^{2}
$$

Gini index of inequality. Where $n$ is the number of components, $i$ is the rank by decreasing component size, and $x_{i}$ is the fractional share of the $i$ th component, then the Gini index expresses the extent of inequality in the set:

$$
G=\frac{n+1}{n}-\frac{2 \sum_{1}^{n}(n+1-i) x_{i}}{n \sum_{1}^{n} x_{i}}
$$

Population standard deviation. Where $\mathrm{N}$ is the size of the population, $\mathrm{x}_{i}$ each value from the population, $\mu$ is the population mean and $\sigma$ is the population standard deviation, then

$$
\sigma=\sqrt{\frac{1}{N} \sum_{i=1}^{N}\left(x_{i}-\mu\right)^{2}}
$$

Higher HHI or Gini numbers indicate, respectively, greater concentration and greater inequality, while lower HHI or Gini numbers indicate less concentration and less inequality (for discussion, Taagepera 1979). The standard deviation measures how spread out numbers are relative to the mean; a higher standard deviation indicates wider dispersion.

\section{Implications and Hypotheses}

Given the constitutional ban on inter-party competition, Cuba's official leadership has looked for supplementary claims that its national institutions are inclusive. "Descriptive inclusion" on the Council of State permits but it does not demonstrate that those included actively represent their respective descriptive categories. The evidence of representative behaviour is meagre; further research would be required to ascertain the extent of representativeness. Nevertheless, current official claims highlight gender and racial inclusion. Given the territorial basis for the selection of National Assembly members, territorial inclusion could be a third politically permitted descriptive criterion for the Assembly and the Council of State. Therefore, 
Hypothesis 1. The share of Council of State members from each province reflects the national population share of each province across time and presidencies. Council membership shares should not be concentrated in a few provinces. Tests. The Herfindahl-Hirschman Index (HHI), the Gini index, and the inter-provincial standard deviation should be low, mirror the provincial population indexes each year and vary little over time.

However, the contemporary PCC is heir to a revolutionary tradition. Its political role is emblazoned in the 2019 Constitution's Article 5 as the "organised vanguard of the Cuban nation" that acts as the "superior political force directing the State and society". Hence, the nation, not the province, is paramount. Providing for provincial inclusion would not be a necessary criterion for Council membership selection. As in other revolutions, the regime's foundation propels a leadership elite that persists. Therefore,

Hypothesis 2. Council of State membership reflects vanguard party criteria, namely, the predominance of the original revolutionary vanguard that governs a centralised unitary state. The share of Council members should be greater from the founding revolutionary province (Santiago) and from national government headquarters (City of Havana) across time. Tests. Council membership should be disproportionately concentrated in two provinces. The Herfindahl-Hirschman Index (HHI), the Gini index and the interprovincial standard deviation should be high and should differ from the provincial population indexes each year.

Historical conjunctures may shape the Council's membership. F. Castro's (1926-2016) leadership was one of a kind. He had much discretion to choose Council members. With his effective departure from the presidency in 2006, subsequent configurations of the Council's membership should show a discontinuity between F. Castro's last Council (2003) and R. Castro's (2008, 2013) and Díaz-Canel's (2018) respective Councils. The latter two lacked F. Castro's clout; thus, they looked for supplementary means to secure support. Therefore,

Hypothesis 3. Council membership reflects changing criteria across time. F. Castro may have ignored spatial inclusion, yet his successors must be geographically inclusive. Moreover, R. Castro is a revolutionary founder a giant of the 1950 s rebellion and decades of subsequent rule - while Díaz-Canel was born in 1960, after revolutionary victory, and served on high posts only in the current century. R. Castro should have somewhat wider discretion than Díaz-Canel to attend less to spatial inclusion. Tests. 
The geographic concentration of Council membership (HHI) should fall markedly, and its geographic distribution should become much more equal (Gini index and inter-provincial standard deviation), between F. Castro's last Council and R. Castro's and Díaz-Canel's Councils. Moreover, the concentration index (HHI) and the standard deviation should fall somewhat, and the differences in inequality (Gini index and standard deviation) should lessen, between R. Castro's last Council and Díaz-Canel's first.

Finally, the disproportionate spatial concentration of Afrodescendants highlights the pre-revolutionary communist party diagnosis, namely, to recognise a "black belt" region in Cuba's three easternmost provinces. Therefore,

Hypothesis 4. Council of State membership should match the racial distribution of the population in each province. Hence, Council members from the three easternmost provinces should be disproportionately Afrodescendants, as should half of Havana's, whereas Council members from each of the other provinces should be zero. Tests. The indexes for the expected and actual Afrodescendant distributions should be approximately the same, with little change over time. The HHI, Gini index and standard deviation should be high for both expected and actual Afrodescendant Council members.

\section{Findings}

Membership on the Council of State by province varied across the four Councils selected in the 21st century. Table 1 lists the relative shares of the population and Council seats per province per year. All provinces except the city of Havana have a population below $10 \%$ of the country's total. The population shares of each province varied little over time.

In 2003, under F. Castro's last Council presidency, five of the fourteen provinces had no National Assembly Deputy on the Council. On the other hand, the City of Havana's and the province of Santiago de Cuba's shares of Council membership were, respectively nearly two-thirds higher and over three times higher than their shares of the provincial population. In 2008, under R. Castro's first Council presidency, only two provinces lacked a Deputy on the Council. In 2013 and 2018, only one province was absent from the Council. In 2018, the shares of Council membership reasonably matched the shares of the respective provincial population.

The indexes reported at Table 2 assess the shares of concentration, inequality and dispersion across provinces and Councils. Those indexes for the provincial 


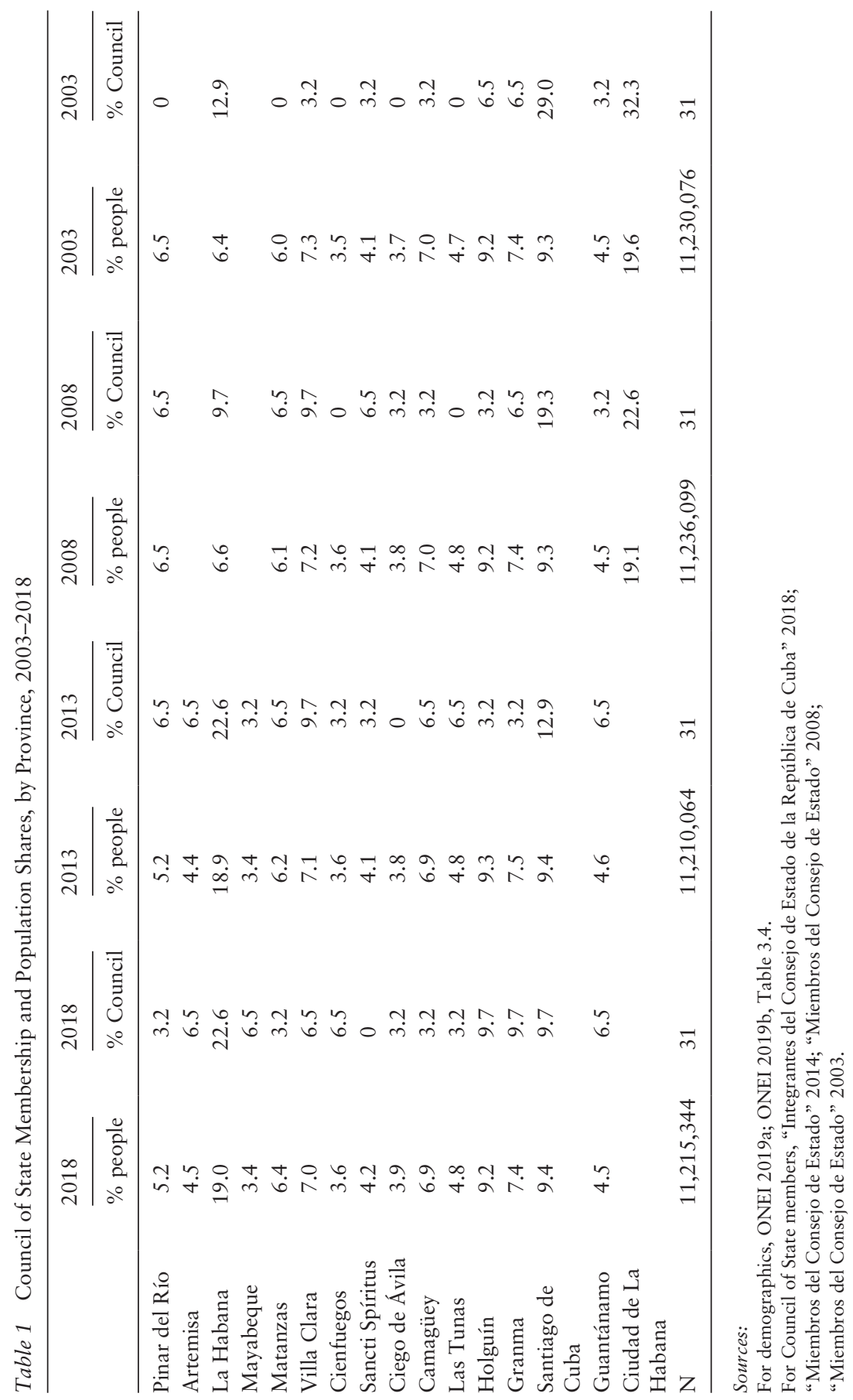


Table 2 Concentration, Inequality, and Dispersion Indexes, 2003-2018

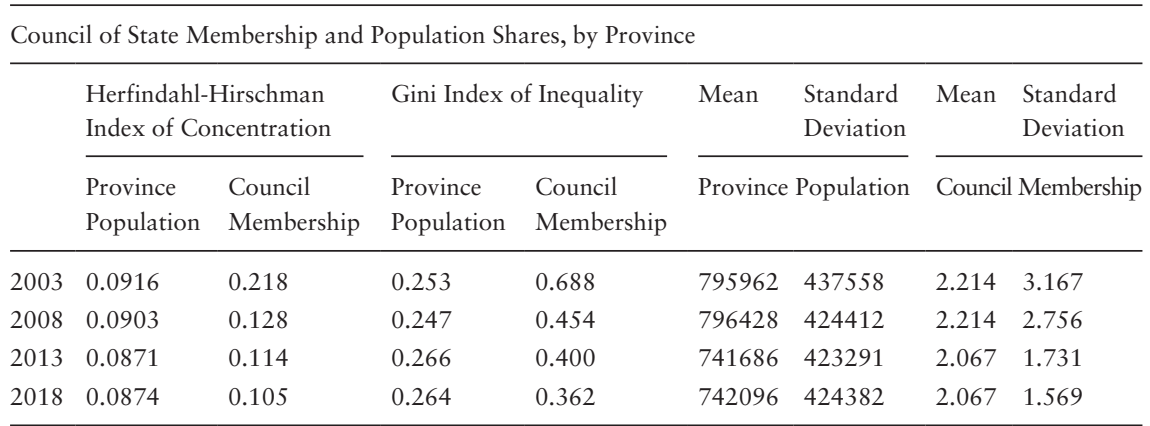

Source: Calculated from Table 1.

population shares varied little from 2003 to 2018. However, in 2003, concentration and inequality of Council membership shares were appreciably higher than the indexes for the provincial population shares. The HHI and the Gini dropped by 2008, sliding gradually in 2013 and 2018. In 2018, the concentration index is nearly similar for province population share and Council membership share; the Gini indexes for inequality are also much closer. Mean Council membership changed little but the standard deviation dropped much more; in 2003, the numbers for Council membership spread widely across the provinces (from the City of Havana's ten and Santiago's nine to zero from five other provinces). In contrast, there was much less spread as the years passed, with all but two provinces having one to three Council members in 2018.

Contrary to the first hypothesis, therefore, there was substantial variation in the indexes across time. The concentration, inequality and dispersion shown in the Council membership indexes are markedly higher in 2003. There was concentration in the Santiago de Cuba and Ciudad de La Habana provinces. The Gini indexes for Council membership shares were highly unequal and different from the population distribution across provinces; the inter-provincial spread was much wider. Hence, there was little spatial inclusion in 2003 . However, the first hypothesis characterises accurately enough the situations beginning in 2008 and especially in 2013 and 2018; for those years, the Council's membership share indexes increasingly mirrored the population of each province, while dispersion was also mitigated, and spatial inclusion became the norm.

Turning to the second hypothesis, in 2003 the original revolutionary vanguard predominated; seven of the nine Council members from Santiago de Cuba province were veterans of the 1950s rebellion; the HHI, Gini index and standard deviation were much higher than happened in the three subsequent Council years. In 2008, four of the six from Santiago were still rebellion veterans, when 
Santiago province's share of Council membership was still twice its provincial population share. Ageing, infirmity and death reduced the numbers of rebellion veterans from Santiago to three out of four in 2013, but none in 2018. Moreover, high government and party officials accounted for seven of the ten from City of Havana in 2003, six of the seven each in 2008 and 2013, but only three of the seven in 2018.

The second hypothesis fares very well under F. Castro in 2003 but also well enough in 2008 and 2013 regarding both the provinces of Santiago and City of Havana: rebellion veterans and high government officials prevailed. Veteran and bureaucratic inclusion trumped spatial inclusion. The presence of veterans and bureaucrats waned only in 2018, when a political decision prior to the Council's selection cut the number of high government officials. The 2019 Constitution's Article 121 confirmed that decision, barring all Council of Ministers members from serving on the Council of State.

The noteworthy difference between F. Castro's last Council and the following three Councils confirms the key proposition of the third hypothesis. F. Castro could ignore spatial inclusion, while his successors leaned on it to bolster support. The concentration and inequality indexes dropped markedly after 2003; the dispersion index dropped as well, though more moderately. However, the differences on the concentration and Gini indexes between R. Castro's two Councils and Díaz-Canel's first are modest (although both dropped slightly, as expected, between R. Castro's last and Díaz-Canel's first), while the standard deviation continued to slide. In short, F. Castro's towering presence accounted for the lack of territorial inclusion in 2003; his retirement accounted for the subsequent one-time drop on the three indexes. R. Castro's and Díaz-Canel's spatial inclusion strategies were approximately similar.

The fourth hypothesis ponders the relationship between territoriality and the distribution of the Afrodescendant population. Three-quarters of the people in the provinces of Santiago de Cuba and Guantánamo were non-white as was a majority of Granma province and nearly half in the city of Havana (see Table 3).

If Council membership were to reflect a province's racial distribution, the expected number of Afrodescendants on the Council would be high for those four provinces, relative to their assigned seats on the Council. Yet, as Santiago and Guantánamo provinces show most clearly, from 2003 to 2013 Afrodescendants accounted at most for half of Santiago's and none of Guantánamo's expected Council members. Only in 2018 did Santiago's expected and actual numbers of Council Afrodescendants match, and only then did Guantánamo have an Afrodescendant Council member.

The Council's overall racial demographics also changed. The number of Afrodescendants on the Council expanded from ten to eleven from F. Castro's 


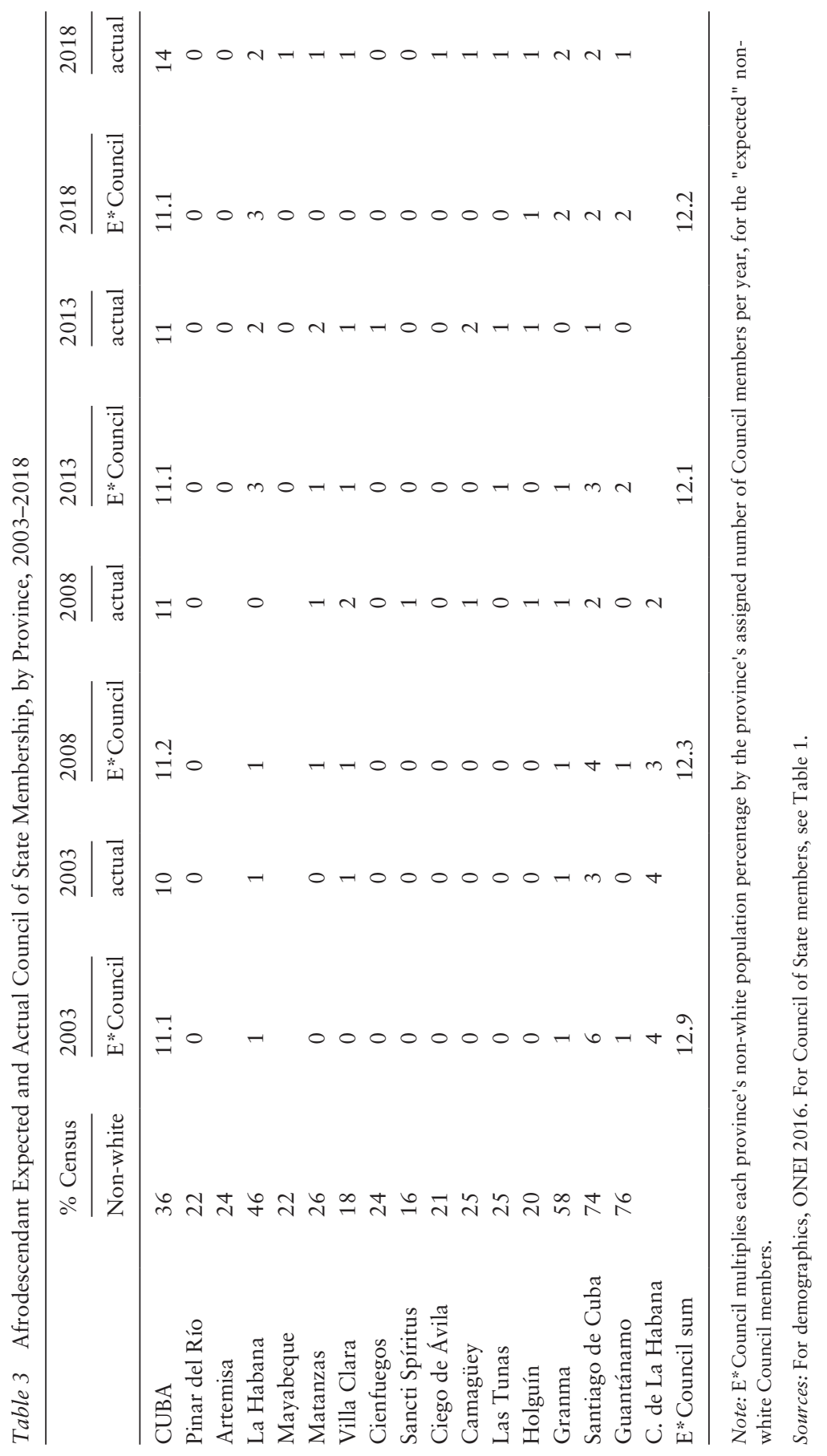


last Council to R. Castro's two Councils, rising to 14 for Díaz-Canel's first. The number of provinces with an Afrodescendant Council member was five in 2003 and eight in 2008 (both out of 14 provinces), eight in 2013 and eleven in 2018 (both out of 15 provinces). In 2018, six provinces had an Afrodescendant Council member although the expected number for each was zero. Thus, the standard deviation for actual Afrodescendant members was cut in half between 2003 and 2018 because dispersion fell between those years (Table 4).

The concentration, inequality and dispersion indexes shed additional light. The indexes for the expected number of Afrodescendant Council members per province per year are consistently different and higher than the actual number of such members. The three indicators for the expected members rest on the demographic distribution of Afrodescendants in each province, whereas the actual membership reflects political decisions independent of the Afrodescendant share of a province's population.

Between 2003 and 2013, the expected membership indicators suggested that there should be more Afrodescendants from the three easternmost provinces and the City of Havana than was the case. Contrary to the fourth hypothesis, Afrodescendants from those four provinces were under-represented. The PCC leadership that proposes the slate of Council members decoupled territoriality and race from Council membership. Inclusion on the Council reflected a national political choice, not the demography of each province. Thus, there were more Afrodescendants from Afrodescendant-minority provinces on the Council than would have been demographically expected. This approach fit well with the

Table 4 Concentration, Inequality and Dispersion Indexes, 2003-2018

Afrodescendant Expected and Actual Council of State Membership, by Province

\begin{tabular}{|c|c|c|c|c|c|c|c|c|}
\hline & \multicolumn{2}{|c|}{$\begin{array}{l}\text { Herfindahl- } \\
\text { Hirschman } \\
\text { Concentration Index }\end{array}$} & \multicolumn{2}{|c|}{$\begin{array}{l}\text { Gini Index of } \\
\text { Inequality }\end{array}$} & \multirow{2}{*}{$\begin{array}{l}\text { Mean } \\
\text { Expected }\end{array}$} & \multirow{2}{*}{$\begin{array}{l}\text { Standard } \\
\text { Deviation } \\
\text { Expected }\end{array}$} & \multirow{2}{*}{$\begin{array}{l}\text { Mean } \\
\overline{\text { Actual }}\end{array}$} & \multirow{2}{*}{$\begin{array}{l}\text { Standard } \\
\text { Deviation } \\
\text { Actual }\end{array}$} \\
\hline & Expected & Actual & Expected & Actual & & & & \\
\hline 2003 & 0.446 & 0.280 & 0.786 & 0.757 & 0.928 & 1.751 & 0.714 & 1.221 \\
\hline 2008 & 0.221 & 0.140 & 0.655 & 0.526 & 1.007 & 1.626 & 0.786 & 0.773 \\
\hline 2013 & 0.163 & 0.140 & 0.535 & 0.558 & 0.800 & 1.046 & 0.733 & 0.772 \\
\hline 2018 & 0.148 & 0.102 & 0.720 & 0.382 & 0.667 & 1.011 & 0.933 & 0.680 \\
\hline
\end{tabular}

Note: For Census \% non-white, the HHI is 0.016; the Gini Index is 0.286; the mean is 0.071; and the standard deviation is 0.038 .

Source: Calculated from Table 3. 
radically integrative objective of revolutionary parties and the official beliefs of Cuban leaders, denying that racism persists in policies or practices in postrevolutionary Cuba.

However, under Díaz-Canel, the first Council president born after the 1959 revolutionary victory, both spatial and racial inclusion helped to gather political support. In 2018, for the first time the actual and expected numbers of Afrodescendants from the three easternmost provinces and Havana were almost the same. Because the number of Afrodescendants on the Council had increased, it also became possible to continue to include them from provinces where demographically they would not have been expected.

Thus, in 2018 Afrodescendants were included on the Council of State, drawn from across most provinces. Afrodescendant-dominant provinces received their demographic due on the Council in 2018 but no additional allocation, while under F. Castro and Raúl Castro they had received neither their demographic due nor additional allocations.

\section{Conclusion}

Cuba's national leadership designed the National Assembly to draw Deputies from territorial districts, thereby ensuring that the population of the provinces would be reflected in the Assembly's composition. The choice of Council of State members was not constrained by territoriality, however. The national leadership has never indicated that spatial inclusion must be a criterion for Council membership.

Spatial inclusion had not been a concern for F. Castro as Council president. However, spatial inclusion increased substantially under the R. Castro and Díaz-Canel Council presidencies. Under the latter two, the spatial distribution of Council membership became less concentrated or unequal. Hence, the first hypothesis did not describe F. Castro's Council presidency, but it approximated the other two. Whereas under F. Castro several provinces had no one on the Council, under R. Castro and Díaz-Canel nearly all did. These two leaders touted their success in ensuring that the Council's gender and racial distribution would reflect the nation's people. They could have also celebrated, but have not yet, that the Councils that they have headed include members from across the provinces.

The preference for including rebellion veterans and national bureaucrats on the Council, a finding consistent with the second hypothesis, had been a key reason for spatial concentration over time, most so under F. Castro. Rebellion veterans came disproportionately from Santiago province. The number of veterans on the Council fell principally because of ageing and death. The reduction of 
national bureaucrats on the 2018 Council resulted, however, from an explicit political decision in advance of its choosing.

Spatial inclusion improved under R. Castro and Díaz-Canel. F. Castro towered over Cuban politics and believed he did not have to worry as much about racial, gender or spatial inclusion. Thus, the end of F. Castro's presidency was a key turning point regarding descriptive spatial inclusion on the Council, a finding consistent with the third hypothesis; only after Fidel did top leaders have an incentive to reach out beyond the few rebellion veteran officers.

In 1934, Cuba's communist party recognised the disproportionate concentration of the Afrodescendant population in south-eastern Cuba; it endorsed according that ethno-racial region significant subnational autonomy. The party soon reversed that decision, and the post-revolutionary communist party never endorsed it. Nevertheless, in the 21st century the number of Afrodescendants on the Council increased and came to reflect their share of the national population. At the same time, contrary to the fourth hypothesis, racial and territorial factors were ordinarily decoupled in the configuration of Council membership across the three presidencies.

Relative to the Afrodescendant share of each province's population, there have been more Afrodescendant Council members than demographically would be expected in Afrodescendant-minority provinces and, from 2003 to 2013, fewer than demographically would be expected in Afrodescendantmajority provinces. Hence, from 2003 to 2013 Afrodescendants were overrepresented on the Council in provinces where their population share was small and, until 2018, under-represented where they were a demographic majority. Above all, Afrodescendant inclusion on the Council reflects the national share of Afrodescendants, not their relative presence in various provinces. In 2018, as the first president born following the 1959 revolutionary victory and thus in search of supplementary support, Díaz-Canel's Council accorded the Afrodescendant majority provinces their demographic due on the Council - the first such time.

In this fashion, communist Cuba rejected the approach to ethnic-based formal federalism pioneered in the Soviet Union. It also rejected reserving seats for ethnic minorities on the constitutional institutions, contrary to practices in China, Vietnam and Laos. Cuba's official colour blindness resembles, instead, the Latin American experience that denies the political importance of racial differences. It also underscores the political commitment to integrate radically across the colour spectrum and subordinate all such differences to the communist party's overarching goals. For Cuba's PCC leadership, there are no black Cubans or white Cubans - there are only Cubans. That view, however, 
under-emphasises the significant, persisting social and economic inequalities between Cubans across that colour spectrum, which could someday become the basis for political expression and association.

\section{References}

Castro, Raúl (2018) “El Partido Comunista apoyará y respaldará resueltamente al nuevo presidente", Granma, 20 April. http://www.granma.cu/elecciones-encuba-2017-2018/2018-04-20/el-partido-comunista-apoyara-y-respaldara-resueltamente-al-nuevo-presidente/. (Accessed 20 April 2018.)

Consejo de Estado (2020) "Consejo de Estado de Cuba aprueba seis decretos-leyes", Granma, 20 April. http://www.granma.cu/cuba/2020-04-22/consejo-de-estado-decuba-aprueba-seis-decretos-leyes-22-04-2020-18-04-53. (Accessed 22 April 2020.)

Constitución de la República de Cuba (2019) http://www.granma.cu/file/pdf/gac eta/Nueva\%20Constituci\%C3\%B3n\%20240\%20KB-1.pdf/. (Accessed 11 August 2020.)

Degras, Jane (ed.) (1959) The Communist International, 1919-1943. Documents. Vol. II, 1923-1928. London: Royal Institute of International Affairs.

De la Fuente, Alejandro (2001) A Nation for All: Race, Inequality, and Politics in Twentieth-Century Cuba. Chapel Hill, NC: University of North Carolina Press.

Díaz-Canel, Miguel (2018). “Asumo la responsabilidad con la convicción de que todos los revolucionarios seremos fieles al ejemplar legado de Fidel y Raúl”, Granma, 20 April. http://www.granma.cu/elecciones-en-cuba-2017-2018/2018-04-20/asumo-laresponsabilidad-de-que-todos-los-revolucionarios-seremos-fieles-al-ejemplar-legadode-fidel-y-raul/. (Accessed 20 April 2018.)

Espina Prieto, Mayra and Togores González, Viviana (2012) "Structural change and routes of social mobility in today's Cuba: patterns, profiles, and subjectivities", in Jorge I. Domínguez, Omar Everleny Pérez Villanueva, Mayra Espina Prieto and Lorena Barberia (eds), Cuban Economic and Social Development. Cambridge, MA: Harvard University Press, 261-91.

Government of Lao People's Democratic Republic (2006) Indigenous Peoples Development Planning. Manila: Asian Development Bank.

Hansing, Katrin and Hoffmann, Bert (2020) "When racial inequalities return: assessing restratification of Cuban society 60 years after revolution", Latin American Politics and Society, 5(2), 29-52.

"Integrantes del Consejo de Estado de la República de Cuba" (2018) Cubadebate, http:// www.cubadebate.cu/cu/cuba/consejo-estado/. (Accessed 22 August 2018.)

Inter-Parliamentary Union (2011) Lao People's Democratic Republic Sapha Heng Xat (National Assembly). http://archive.ipu.org/parline-e/reports/arc/2175_11.htm. (Accessed 12 September 2018.)

Inter-Parliamentary Union (2018) China: Quanguo Renmin Daibiao Dabui (National People's Congress). http://archive.ipu.org/parline-e/reports/2065_B.htm. (Accessed 14 September 2018.) 
“Miembros del Consejo de Estado" (2003) Granma, 6 March. http://www.granma.cu/ granmad/2003/03/06/nacional/articulo16.html. (Accessed 11 August 2020.)

"Miembros del Consejo de Estado" (2008) Granma, 25 February. http://www.granma. cubaweb.cu/2008/02/25/nacional/artic04.html. (Accessed 25 February 2008.)

“Miembros del Consejo de Estado" (2014) Granma, 11 March. http://www.granma.cu/ granmad/secciones/estado_cubano_consejoestado. (Accessed 14 August 2018.)

ONEI (Oficina Nacional de Estadística e Información) (2016) El color de la piel según el Censo de Población y Viviendas: Cuba, 2012. Havana: República de Cuba.

ONEI (Oficina Nacional de Estadística e Información) (2019a) Anuario demográfico de Cuba, 2018. Havana: República de Cuba.

ONEI (Oficina Nacional de Estadística e Información) (2019b) Series estadísticas población 1985-2018. Havana: República de Cuba, table 3.4.

Palmieri, Sonia (2010) Representation from the Top: Ethnic Minorities in the National Assembly of Vietnam. New York: United Nations Development Program. https:// www.refworld.org/docid/51e7bf234.html. (Accessed 8 December 2018.)

Reynolds, Andrew (2005) "Reserved seats in national legislatures: a research note", Legislative Studies Quarterly, 30(2), 301-10.

Rice, Roberta (2020) “Contemporary indigenous issues”, Canadian Journal of Latin American and Caribbean Studies, 45(1), 1-4.

Riker, William (1964) Federalism: Origin, Operation, Significance. Boston: Little, Brown. Sawyer, Mark (2006) Racial Politics in Post-Revolutionary Cuba. New York: Cambridge University Press.

Taagepera, Rein (1979) “Inequality, concentration, imbalance”, Political Methodology, 6(3), 275-91. 